\title{
Foliar phenolic compounds of ten wild species of Verbenacea as antioxidants and specific chemomarkers
}

\author{
J. A. Ávila-Reyes ${ }^{a}$, N. Almaraz-Abarca ${ }^{*}$, A. I. Chaidez-Ayala ${ }^{a}$, D. Ramírez-Noya ${ }^{a}$, \\ E. A. Delgado-Alvarado ${ }^{a}$, R. Torres-Ricario ${ }^{a}$, N. Naranjo-Jiménez ${ }^{a}$ and R. E. Alanís-Bañuelos ${ }^{b}$ \\ aLaboratorio de Biotecnología, Centro Interdisciplinario de Investigación para el Desarrollo Integral Regional - CIIDIR, \\ Instituto Politécnico Nacional - IPN, CP 34220, Calle Sigma, 119, Durango, Dgo., México \\ ${ }^{b}$ Facultad de Ciencias Químicas - FCQ, Universidad Juárez del Estado de Durango - UJED, Campus Gómez Palacio, \\ Avenida Artículo, 123, CP 35015, Gómez Palacio, Dgo., México \\ *e-mail: nalmaraz@ipn.mx, noralab@yahoo.com
}

Received: May 23, 2016 - Accepted: August 16, 2016 - Distributed: February 28, 2018

(With 2 figures)

\begin{abstract}
The family Verbenaceae hosts important species used in traditional medicine of many countries. The taxonomic controversies concerning the specific delimitation of several of its species make it difficult to guarantee the botanical origin of herbal preparations based on species of this family. To contribute to the development of both specific chemomarkers and a quality control tool to authenticate the botanical origin of herbal preparations of Verbenacea species, we determined the foliar HPLC-DAD phenolic profiles and the antioxidant properties of 10 wild species of this family occurring in Mexico. The contents of phenols and flavonoids varied significantly among species. Priva mexicana showed the highest levels of total phenolics (53.4 $\mathrm{mg} \mathrm{g}^{-1}$ dry tissue) and Verbena carolina had the highest levels of flavonoids (17.89 $\mathrm{mg} \mathrm{g}^{-1}$ dry tissue). Relevant antioxidant properties revealed by antiradical and reducing power were found for the analyzed species. These properties varied significantly in a species-dependent manner. The phenolic compounds accumulated were flavones and phenolic acids. Flavones were the only type of flavonoids found. The results of a cluster analysis showed that the compounds were accumulated in species-specific profiles. The phenolic profiles are proposed as valuable chemomarkers that can become a useful tool for the quality control concerning the botanical origin of herbal medicinal preparations based on the species analyzed. In addition, phenolic profiles could contribute importantly to solve the taxonomic controversies concerning species delimitation in the family Verbenaceae.
\end{abstract}

Keywords: Verbenacea, antioxidant activity, chemomarkers, flavones, phenolic profiles.

\section{Compostos fenólicos das folhas de dez especies selvagem de Verbenaceae como antioxidantes e quimiomarcadores específicos}

\begin{abstract}
Resumo
A família Verbenaceae compreende importantes espécies utilizadas na medicina popular de muitos países. As dificuldades taxonômicas relativas à delimitação específica de muitas das suas espécies face difícil a verificar a origem botânico das preparações herbales baseadas nas espécies desta família. Para fazer uma contribuição ao desenvolvimento de indicadores taxonômicos e dum método de controle de qualidade para verificar a origem botânico de preparações herbales das espécies de Verbenaceae, os perfis fenólicos, obtidos pares HPLC-DAD, e as atividades antioxidantes das folhas de 10 espécies selvagens Mexicanas desta família foram determinados. Os conteúdos dos compostos fenólicos totais e dos flavonoides foram significativamente diferentes entre as espécies. Priva mexicana apresentou a maior quantidade de compostos fenólicos totais (53.4 $\mathrm{mg} \mathrm{g}^{-1}$ amostra seca) e Verbena carolina apresentou a maior quantidade de flavonoides (17.89 $\mathrm{mg} \mathrm{g}^{-1}$ amostra seca). Verifica-se importantes propriedades antioxidantes, como os resultados dos ensaios da capacidade antiradical e do poder redutor indicaram. As propriedades antioxidantes foram significativamente diferentes entre as espécies. Verificou-se que os compostos fenólicos conteúdos nas folhas das espécies analisadas foram só flavonas e ácidos fenólicos. Os resultados das análises de agrupamento provarãn que os perfiles fenólicos foram espécie-específicos. Estes perfis podem ser considerados como indicadores químicos da qualidade relativa à origem botânico de preparações medicinais baseadas nas espécies analisadas e podem fazer importantes contribuições para a delimitação específica na família Verbenaceae.
\end{abstract}

Palavras-chave: Verbenaceae, actividade anti-oxidante, indicadores taxonómicos, flavonas, perfis fenólicos. 


\section{Introduction}

The Verbenaceae family is a taxonomically difficult group of plants. There are many controversies concerning the circumscription of several of its genera, species, and even the own family. Considering what was regarded as subfamily Verbenoideae, now considered as family Verbenaceae, and excluding the genera Callicarpa, Clerodendron, and Tetraclea (now forming part of the family Lamiaceae), Rzedowski and Calderón de Rzedowski (2002) reported about 1000 species belonging to the family Verbenaceae, which occur in template and tropical regions worldwide, mainly in the American continent.

Many species of Verbenacea are used as important folk remedies for the treatment of several human health disorders, like some kinds of cancer and hypertension (Ghisalberti, 2000; Manica-Cattani et al., 2009). Due to the medicinal importance or toxic effects of several species of Verbenaceae, efforts have been made to develop markers that allow distinguishing among species. Some of these efforts have focused on anatomical studies (Calzada-Sánchez et al., 2014; Passos et al., 2009).

Plant phenolic compounds are important natural antioxidants (Shin et al., 2015) that have beneficial effects on human health. For several groups of plants, profiles of these compounds have been reported as worthy chemomarkers because they were species-specific, like Equisetum (Veit et al., 1995), Pinus (Almaraz-Abarca et al., 2006), and Salvia (Kharazian, 2014). The species-specific condition of phenolic profiles could be of taxonomic relevance. In addition, the profiles can represent a quality control tool concerning the botanical origin of plant-based medicinal preparations, as adulteration is a global latent risk for traditional herbal preparations, as documented by Ahmad et al. (2009).

Some species of Verbenaceae have been analyzed to determine their phenolic composition and some biological activities, like Verbena officinalis L. (Calvo et al., 1997), Lantana camara L. (Wollenweber et al., 1997), Vitex polygama Cham. (Gonçalves et al., 2001), and Lampaya medicinalis Phil. (Morales and Paredes, 2014). Phytochemical studies with taxonomical interest are few and have been based mainly on the essential oil composition (Sena Filho et al.,
2012; Satyal et al., 2016). Despite the important studies already done, there are many other species of Verbenaceae to analyze for their phenol composition and antioxidant activity. The present study focused on determining the foliar phenolic profiles and antioxidant activity of Verbena gracilis Desf., V. carolina L., V. bipinnatifida Nutt., V. menthifolia Benth., Lantana camara L., Phyla nodiflora (L.) Greene, Aloysia gratissima (Gill. et Hook) Tronc., Bouchea prismatica (L.) Kuntze, Priva mexicana (L.) Pers., and Lippia umbellata Cav., occurring in Mexico, to assess their potential as specific chemomarkers.

\section{Material and Methods}

\subsection{Plant material}

Leaves of adult flowering plants of 10 species of Verbenaceae were collected from natural populations of Durango, Mexico. Sampling sites are described in Table 1. Voucher specimens were deposited at the Herbarium CIIDIR. For each single species, all leaves of four individuals were combined and three pools of samples were formed and analyzed separately. The dried and ground leaves were kept in plastic bags, in darkness, and stored at room temperature until analysis.

\subsection{Preparation of extracts}

For each pool of samples, phenols were extracted from $4 \mathrm{~g}$ of dry and ground leaves by maceration in $40 \mathrm{~mL}$ of $80 \%$ ethanol (v/v) for $24 \mathrm{~h}$, shaking at $100 \mathrm{rpm}$, in darkness, at room temperature. The extracts were centrifuged ( $5000 \mathrm{rpm}$, $10 \mathrm{~min}$, at room temperature) and the supernatants decanted. Aliquots were used in the HPLC-DAD analysis and in the antioxidant assays.

\subsection{Total phenolics}

The concentrations of total phenolics were determined using Folin-Ciocalteu reagent, according to Falleh et al. (2011). The phenolic contents were calculated from a standard curve of gallic acid $\left(\mathrm{A}_{760 \mathrm{~nm}}\right.$, slope $=104.190$, $y$ axis crossing point $=-0.0093$, correlation coefficient $\mathrm{r}=0.9985$ ). Total phenolic concentrations were expressed as milligrams gallic acid equivalents per gram of dry tissue (mg GAE g ${ }^{-1} \mathrm{dt}$ ).

Table 1. Collection sites for 10 species of Verbenaceae from Mexico.

\begin{tabular}{clllllr}
\hline $\begin{array}{c}\text { Curatorial } \\
\text { number }\end{array}$ & \multicolumn{1}{c}{ Species } & \multicolumn{1}{c}{ Location } & $\begin{array}{c}\text { Latitude } \\
(\mathbf{N})\end{array}$ & $\begin{array}{c}\text { Longitude } \\
(\mathbf{W})\end{array}$ & $\begin{array}{c}\text { Altitude } \\
(\mathbf{m})\end{array}$ & Date \\
\hline 45018 & Verbena gracilis & Durango & $24^{\circ} 03^{\prime} 04^{\prime \prime}$ & $104^{\circ} 36^{\prime} 41^{\prime \prime}$ & 1,876 & June $30 / 2014$ \\
45307 & Phyla nodiflora & Durango & $23^{\circ} 57^{\prime} 40^{\prime \prime}$ & $104^{\circ} 35^{\prime} 05^{\prime \prime}$ & 1,877 & July $9 / 2014$ \\
45308 & Verbena carolina & Vicente Guerrero & $23^{\circ} 44^{\prime} 58^{\prime \prime}$ & $103^{\circ} 58^{\prime} 48^{\prime \prime}$ & 1,933 & Aug $8 / 2014$ \\
45310 & Lantana camara & Durango & $24^{\circ} 00^{\prime} 47^{\prime \prime}$ & $104^{\circ} 23^{\prime} 33^{\prime \prime}$ & 1,951 & Aug $8 / 2014$ \\
45311 & Verbena bipinnatifida & Nombre de Dios & $23^{\circ} 47^{\prime} 43^{\prime \prime}$ & $103^{\circ} 50^{\prime} 48^{\prime \prime}$ & 2,212 & Aug $15 / 2014$ \\
45309 & Aloysia gratissima & Durango & $24^{\circ} 00^{\prime} 43^{\prime \prime}$ & $104^{\circ} 26^{\prime} 02^{\prime \prime}$ & 1,860 & Aug $15 / 2014$ \\
45315 & Bouchea prismatica & Durango & $24^{\circ} 00^{\prime} 43^{\prime \prime}$ & $104^{\circ} 26^{\prime} 02^{\prime \prime}$ & 1,860 & Sept $26 / 2014$ \\
45314 & Verbena menthifolia & Durango & $24^{\circ} 00^{\prime} 43^{\prime}$ & $104^{\circ} 26^{\prime} 02^{\prime \prime}$ & 1,860 & Sept $26 / 2014$ \\
45378 & Priva mexicana & Vicente Guerrero & $23^{\circ} 48^{\prime} 43^{\prime \prime}$ & $105^{\circ} 52^{\prime} 14^{\prime \prime}$ & 2,263 & Oct $2 / 2014$ \\
45313 & Lippia umbelata & Tamazula & $25^{\circ} 26^{\prime} 02^{\prime \prime}$ & $106^{\circ} 56^{\prime} 28^{\prime \prime}$ & 1,507 & Oct $9 / 2014$ \\
\hline
\end{tabular}




\subsection{Total flavonoids}

Flavonoid contents were determined by using $\mathrm{AlCl}_{3}$, according to Falleh et al. (2011), from a standard curve of apigenin $\left(\mathrm{A}_{425 \mathrm{~nm}}\right.$, slope $=111.111, y$ axis crossing point $=-0.0021$, correlation coefficient $r=0.9988$ ). Flavonoid contents were expressed as milligrams apigenin equivalents per gram of dry tissue $\left(\mathrm{mg} \mathrm{AE} \mathrm{g}^{-1} \mathrm{dt}\right)$.

\subsection{HPLC-DAD analysis}

Phenolic compositions were obtained from a gradient method previously described (Campos and Markham, 2007), with a Perkin Elmer Series 200 HPLC system and a Perkin Elmer Brownlee Analytical C18 column $(4.6 \times 250 \mathrm{~mm}, 5 \mu \mathrm{m})$. Water adjusted to $\mathrm{pH} 2.5$ with orthophosphoric acid was solvent A and acetonitrile was solvent B. Solvents were mixed according to the following gradient: starting with $100 \% \mathrm{~A}$, decreasing to $91 \%$ over the next $12 \mathrm{~min}$, to $87 \%$ over the next $8 \mathrm{~min}$, and to $67 \%$ over the next $12 \mathrm{~min}$, and to $57 \%$ until the end of the $60 \mathrm{~min}$ analysis. Chromatograms were registered at $260 \mathrm{~nm}$. Fifty microliters of samples were injected. The flow rate used was $0.8 \mathrm{~mL} \mathrm{~min}^{-1}$. The analyses were carried out at $25^{\circ} \mathrm{C}$. Spectral data for all peaks were accumulated in the range of 200 to $400 \mathrm{~nm}$ using diode-array detection (Perkin Elmer Series 200). Structural information was obtained by comparisons of retention times (RT) and UV spectra of resolved compounds with those of reference compounds (apigenin: RT: $59.62, \lambda_{\text {max }}: 269,335$; chlorogenic acid: RT: $\left.28.16, \lambda_{\max }: 243 \mathrm{sh}, 293 \mathrm{sh}, 325\right)$, as well as with the principles of the UV theory developed by Campos and Markham (2007) for flavonoids and phenolic acids. The foliar phenol profile of each species was made up of all compounds present in the respective HPLC-DAD chromatogram, treating each compound as a single chemical character.

\subsection{Free radical scavenging activity}

The DPPH* method described by Yang et al. (2008) was used to evaluate the free radical scavenging activity. A standard curve of DPPH* $\left(\mathrm{A}_{523 \mathrm{~nm}}\right.$, slope $=0.0309, y$ axis crossing point $=0.0019$, correlation coefficient $r=0.9996$ ) was used to estimate the DPPH* concentration $\left(\mu \mathrm{g} \mathrm{mL}^{-1}\right)$ in the reaction medium. Antiradical activities were expressed in terms of $\mathrm{EC}_{50}$ (concentration of extract needed to decrease by $50 \%$ the initial concentration of $\mathrm{DPPH}^{*}$ ) in micrograms per milliliter $\left(\mu \mathrm{g} \mathrm{mL}^{-1}\right)$. Quercetin and epicatechin were used as reference samples and assayed in the same manner.

\subsection{Total antioxidant capacity (TAC)}

The TAC of each extract was evaluated according to Prieto et al. (1999). The absorbance of the reaction mixtures was registered at $695 \mathrm{~nm}$. The TAC values were calculated from a standard curve of ascorbic acid $\left(\mathrm{A}_{695 \mathrm{~nm}}\right.$, slope $=4.213, y$ axis crossing point $=0.02365$, correlation coefficient $r=0.998$ ) and expressed as milligrams ascorbic acid equivalents per $\mathrm{mL}\left(\mathrm{mg} \mathrm{AAE} \mathrm{mL}^{-1}\right)$. Quercetin and epicatechin were analyzed as reference samples in the same manner.

\subsection{Iron reducing power $(R P)$}

The RP values were calculated by using the method described by Yang et al. (2008). For each sample, a graph of absorbance at $700 \mathrm{~nm}$ vs. increased extract concentrations was constructed to calculate the extract concentration providing 0.5 of absorbance (defined as $\mathrm{IC}_{50}$ ). $\mathrm{RP}$ was expressed as micrograms per milliliter $\left(\mu \mathrm{g} \mathrm{mL}^{-1}\right)$. Quercetin and epicatechin were analyzed in the same manner as references.

\subsection{Data analysis}

Each assay was made for three independent samples of each item. Data were subjected to an analysis of variance $(p \leq 0.05)$ and means were separated by Tukey test. Correlations between different parameters were carried out with Pearson test, using the SPSS Statistics 17.0 computer program. The foliar phenolic profiles were constructed with all compounds resolved in the respective HPLC-DAD chromatograms; each compound representing a single chemical attribute. To determine the species-specific condition of the foliar phenolic profiles, a presence-absence matrix, formed by all individual samples vs. all resolved compounds (10 samples vs. 47 phenolic compounds) was analyzed using Cluster Analysis (Paired Group algorithm, Jaccard similarity measure) from Past 1.43 (Hammer et al., 2001).

\section{Results}

\subsection{Phenolic and flavonoid contents}

The foliar phenolic and flavonoid contents estimated for each species are displayed in Table 2. Priva mexicana showed the highest levels of total phenolics $\left(53.4 \mathrm{mg} \mathrm{g}^{-1} \mathrm{dt}\right)$ and L. camara and A. gratissima accumulated the lowest levels (14.6 and $15 \mathrm{mg} \mathrm{g}^{-1} \mathrm{dt}$, respectively). The levels of foliar flavonoids ranged from 6.6 to $17.8 \mathrm{mg} \mathrm{g}^{-1} \mathrm{dt}$ for L. camara and V. carolina, respectively. Flavonoids accounted for between 22 and 84\% (Lippia umbelata and Aloysia gratissima, respectively) of total phenolics.

\subsection{Antioxidant properties and their correlations with phenolic and flavonoid contents}

The values of the antiradical activities of foliar extracts of the analyzed species are shown in Table 2. The highest activity was found for P. mexicana $\left(\mathrm{EC}_{50}=1.68 \mu \mathrm{g} \mathrm{mL}^{-1}\right)$ and the lowest ones for A. gratissima $\left(\mathrm{EC}_{50}=3.98 \mu \mathrm{g} \mathrm{mL}^{-1}\right)$ and $V$. bipinnatifida $\left(\mathrm{EC}_{50}=3.97 \mu \mathrm{g} \mathrm{mL}^{-1}\right)$. The reducing power values are shown in Table 2 . The lowest extract concentration needed to reach an absorbance value of 0.5 at $700 \mathrm{~nm}$ was that of L. umbelata $\left(1.34 \mu \mathrm{g} \mathrm{mL}^{-1}\right)$, thus, this species displayed the highest reduction power. TAC values are shown in Table 2, the highest capacity was revealed by $V$. menthifolia $\left(6.24 \mathrm{mg} \mathrm{mL}^{-1}\right)$ and the lowest by $A$. gratissima $\left(2.08 \mathrm{mg} \mathrm{mL}^{-1}\right)$.

The kinetic behavior (the monitoring of changes in absorbance at a given wavelength as the result of the reduction of the oxidant by the extracts) of all the antioxidant assays was highly related to phenolic and 
Table 2. Total phenolics, total flavonoids, $\mathrm{DPPH}{ }^{*}$ scavenging capacity $\left(\mathrm{EC}_{50}\right)$, iron reducing power $\left(\mathrm{IC}_{50}\right)$, and total antioxidant capacity (TAC) of 10 species of Verbenacea from Mexico.

\begin{tabular}{|c|c|c|c|c|c|}
\hline Species and standards & $\begin{array}{l}\text { Total phenolics } \\
\left.\text { (mg GAE } \mathrm{g}^{-1} \mathrm{dt}\right)\end{array}$ & $\begin{array}{c}\text { Total } \\
\text { flavonoids } \\
\left(\mathbf{m g ~ A E ~} \mathrm{g}^{-1} \mathrm{dt}\right)\end{array}$ & $\begin{array}{c}\mathrm{EC}_{50} \\
\left(\mu \mathrm{g} \mathrm{mL}^{-1}\right)\end{array}$ & $\begin{array}{c}\mathrm{IC}_{50} \\
\left(\mu \mathrm{g} \mathrm{mL^{-1 }}\right)\end{array}$ & $\begin{array}{c}\text { TAC } \\
\left(\mathrm{mg} \mathrm{AAE} \mathrm{mL}^{-1}\right)\end{array}$ \\
\hline Lantana camara & $14.67 \pm 0.38 \mathrm{a}$ & $6.66 \pm 0.16 a$ & $3.18 \pm 0.02 \mathrm{~g}$ & $5.49 \pm 0.19 \mathrm{~d}$ & $2.32 \pm 0.08 \mathrm{ab}$ \\
\hline Aloysia gratissima & $15.04 \pm 0.15 \mathrm{a}$ & $12.61 \pm 0.27 \mathrm{~d}$ & $3.98 \pm 0.05 \mathrm{i}$ & $9.21 \pm 0.12 \mathrm{~g}$ & $2.08 \pm 0.02 \mathrm{a}$ \\
\hline Verbena bipinnatifida & $16.50 \pm 0.12 b$ & $14.32 \pm 0.20 \mathrm{f}$ & $3.97 \pm 0.01 \mathrm{i}$ & $8.18 \pm 0.31 \mathrm{f}$ & $2.66 \pm 0.10 \mathrm{bc}$ \\
\hline Phyla nodiflora & $16.55 \pm 0.25 b$ & $12.35 \pm 0.31 d$ & $1.81 \pm 0.01 \mathrm{ba}$ & $3.12 \pm 0.24 b$ & $2.54 \pm 0.19 b$ \\
\hline Verbena gracilis & $16.59 \pm 0.62 b$ & $8.60 \pm 0.36 b$ & $3.87 \pm 0.09 \mathrm{~h}$ & $12.72 \pm 0.43 \mathrm{~h}$ & $2.31 \pm 0.03 \mathrm{ab}$ \\
\hline Bouchea prismatica & $24.34 \pm 0.22 \mathrm{c}$ & $10.72 \pm 0.19 \mathrm{c}$ & $2.77 \pm 0.03 f$ & $4.24 \pm 0.06 c$ & $4.48 \pm 0.17 f$ \\
\hline Verbena carolina & $32.45 \pm 0.61 d$ & $17.89 \pm 0.54 \mathrm{~g}$ & $2.60 \pm 0.04 \mathrm{e}$ & $3.84 \pm 0.03 b c$ & $4.25 \pm 0.22 \mathrm{ef}$ \\
\hline Lippia umbelata & $40.65 \pm 0.14 \mathrm{e}$ & $8.99 \pm 0.08 b$ & $1.95 \pm 0.04 \times 10^{-1} \mathrm{c}$ & $1.34 \pm 0.02 \mathrm{a}$ & $3.33 \pm 0.21 \mathrm{~d}$ \\
\hline Verbena menthifolia & $47.68 \pm 0.53 f$ & $13.85 \pm 0.27 f$ & $2.09 \pm 0.01 \mathrm{~d}$ & $6.03 \pm 0.22 \mathrm{~d}$ & $6.24 \pm 0.16 \mathrm{~g}$ \\
\hline Priva mexicana & $53.46 \pm 0.46 \mathrm{~g}$ & $13.24 \pm 0.25 \mathrm{e}$ & $1.68 \pm 0.04 \times 10^{-1} \mathrm{a}$ & $1.71 \pm 0.13 \mathrm{a}$ & $3.93 \pm 0.04 \mathrm{e}$ \\
\hline Quercetin & & & $5.29 \pm 0.39 \mathrm{j}$ & $9.27 \pm 0.23 \mathrm{~g}$ & $8.23 \pm 0.21 \mathrm{~h}$ \\
\hline Epicatechin & & & $14.33 \pm 0.29 \mathrm{k}$ & $7.17 \pm 0.14 \mathrm{e}$ & $2.14 \pm 0.03 c$ \\
\hline
\end{tabular}

GAE: Gallic acid equivalents; AE: Apigenin equivalents; AAE: Ascorbic acid equivalents. The values represent the mean and standard deviation of three independent analysis. Different letters in the same column mean significant differences $(p<0.05)$.

flavonoid contents $(0.9823<\mathrm{r}<0.999)$. However, the correlation analysis revealed lower associations between the antioxidant properties and the phenolic and flavonoid contents in the different samples $(0.0033$ between total phenolics and reduction power $<$ Pearson correlation value $<0.77917$ between total phenolics and DPPH scavenging activity). This means that the antioxidant properties did not increase in parallel to the increase of the levels of total phenolics and total flavonoids in the samples. Extracts having the highest contents of total phenolics or total flavonoids did not always display the highest antioxidant properties, neither the samples having the lowest contents of total phenolics or total flavonoids displayed the lowest antioxidant properties (Table 2).

\subsection{Phenolic composition}

According to the UV theory developed by Campos and Markham (2007), based on of the number of absorption bands; intensity and shape of bands; as well as on the number, position and shape of shoulders in the UV spectra, it is possible to determine the types of phenolic compounds and some $\mathrm{OH}$ - and glycoside-substitutions in their structures. Under our extraction conditions, flavones were the only flavonoids found in the foliar tissues of the analyzed species of Verbenacea. Retention time and $\lambda_{\max }$ for 47 phenolic compounds found are shown in Table 3. Compound 3 was suggested to be chlorogenic acid because its RT (28.37 min) and spectral data ( $\left.\lambda_{\max }: 243 \mathrm{sh}, 293 \mathrm{sh}, 325\right)$ coincided with the respective RT and $\lambda_{\text {max }}$ of this reference compound. Compound 39 was suggested as eupafolin (6-methoxy-5,7,3',4'-tetrahydroxyflavone) based on its spectral data $\left(\lambda_{\max }: 253 \mathrm{sh}, 270,345\right)$, which corresponded to those reported for this compound $\left(\lambda_{\max }: 253.3,269.9,345\right)$ by Wang et al. (2013). A total of 37 flavones were found: eupafolin (compound 34), one tricetin glycoside, one diosmetin glycoside, seven chrysoeriol glycosides, nine scutellarein glycosides, seven apigenin glycosides, and eleven luteolin glycosides. The other phenolics found were chlorogenic acid (compound $\mathbf{3}$ ) and other nine phenolic acids. Chlorogenic acid was found only in the leaves of $A$. gratissima. The phenolic profiles of the analyzed species varied from two phenolic compounds in Lantana camara to 12 in Verbena menthifolia. The chromatograms of each species, showing the UV spectra of some of the major compounds, are displayed in Figure 1. All profiles were species-specific. Except for $V$. gracilis, each species accumulated at least two unique compounds: $P$. nodiflora, compounds 34 and 40; V. carolina, compounds 11 and 14; L. camara, compounds 41 and 47; V. bipinnatifida, compounds 4, 24, 32, 33, 38, 42, and 46; A. gratissima, compounds 3 and 16; $B$. prismatica, compounds 5, 20, 23, and 36; $V$. menthifolia, compounds 17, 30,31, and 37; P. mexicana, compounds 1, 12 and 35; and L. umbelata, compounds $\mathbf{8}$, 18, 21, and 45 (Table 3 ). Figure 2 depicts the dendrogram revealing the species-specific condition of phenolic profiles. The profiles of $V$. gracilis and $V$. carolina were the most similar, with a Jaccard similarity value of 0.6 (Jaccard similarity index of 1 means equality).

\section{Discussion}

The analyzed species of Verbenacea accumulated important levels of total phenolics and flavonoids. Significant $(p \leq 0.05)$ species-dependent variations in both contents were found (Table 2). Considering the foliar total phenolics, seven groups of species were formed. Lantana camara and $A$. gratissima could not be discriminated one from each other according to their levels of accumulated total phenolics, the same was found for $V$. bipinnatifida, $P$. nodiflora and $V$. gracilis. However, the other five species accumulated significantly different total phenolic contents. Priva mexicana showed similar levels of total phenolics 
Table 3. Retention time (RT) and spectral data $\left(\lambda_{\max }\right)$ for the phenolic compounds found in the leaves of 10 species of Verbenaceae.

\begin{tabular}{|c|c|c|c|c|}
\hline $\begin{array}{l}\text { Number of } \\
\text { compound }\end{array}$ & $\begin{array}{c}\text { RT }^{\mathrm{a}} \\
(\mathrm{min})\end{array}$ & $\begin{array}{c}\lambda_{\max } \\
(\mathrm{nm})\end{array}$ & $\begin{array}{c}\text { Proposed types of phenolic } \\
\text { compounds }\end{array}$ & Species \\
\hline 1 & $21.50 \pm 0.00$ & $243 \mathrm{sh}, 295 \mathrm{sh}, 330$ & Phenolic acid & Priva mexicana \\
\hline 2 & $23.42 \pm 0.00$ & 248sh, 297sh, 330 & Phenolic acid & $\begin{array}{l}\text { Priva mexicana } \\
\text { Lippia umbelata }\end{array}$ \\
\hline 3 & $28.37 \pm 0.34$ & $243 \mathrm{sh}, 293 \mathrm{sh}, 325$ & Chlorogenic acid & Aloysia gratissima \\
\hline 4 & $31.94 \pm 0.00$ & 234sh, 266, 335 & Methoxytricetin derivative & Verbena bipinnatifida \\
\hline 5 & $32.12 \pm 0.00$ & 249sh, 269, 336 & Luteolin glucuronide & Bouchea prismatica \\
\hline 6 & $32.87 \pm 0.29$ & 268,335 & Apigenin-7-O-glycoside & $\begin{array}{c}\text { Priva mexicana } \\
\text { Bouchea prismatica }\end{array}$ \\
\hline 7 & $33.59 \pm 0.27$ & $255 \mathrm{sh}, 282,345$ & 6-Hydroxyluteolin glycoside & $\begin{array}{l}\text { Bouchea prismatica } \\
\text { Verbena menthifolia }\end{array}$ \\
\hline 8 & $32.44 \pm 0.00$ & $254,267 \mathrm{sh}, 345$ & Luteolin-7-O-glycoside & Lippia umbelata \\
\hline 9 & $33.19 \pm 0.11$ & $254,267 \mathrm{sh}, 348$ & Luteolin-7-O-glycoside & $\begin{array}{l}\text { Lippia umbelata } \\
\text { Aloysia gratissima }\end{array}$ \\
\hline 10 & $34.24 \pm 0.24$ & 249sh, 289sh, 329 & Phenolic acid & $\begin{array}{c}\text { Priva mexicana } \\
\text { Phyla nodiflora } \\
\text { Verbena menthifolia }\end{array}$ \\
\hline 11 & $34.61 \pm 0.00$ & 282,330 & Scutellarein glycoside & Verbena carolina \\
\hline 12 & $35.01 \pm 0.00$ & 280,333 & Scutellarein glycoside & Priva mexicana \\
\hline 13 & $35.97 \pm 0.23$ & $255,267 \mathrm{sh}, 347$ & Luteolin-7-O-glycoside & $\begin{array}{c}\text { Priva mexicana } \\
\text { Verbena menthifolia } \\
\text { Lippia umbelata }\end{array}$ \\
\hline 14 & $35.49 \pm 0.00$ & 279,332 & Scutellarein glycoside & Verbena carolina \\
\hline 15 & $36.10 \pm 0.28$ & 249sh, 289sh, 330 & Phenolic acid & $\begin{array}{c}\text { Priva mexicana } \\
\text { Verbena menthifolia } \\
\text { Lippia umbelata }\end{array}$ \\
\hline 16 & $35.95 \pm 0.00$ & 267,336 & Apigenin-7-O-glycoside & Aloysia gratissima \\
\hline 17 & $37.22 \pm 0.00$ & $252 \mathrm{sh}, 277,341$ & 6-hydroxyluteolin derivative & Verbena menthifolia \\
\hline 18 & $36.84 \pm 0.00$ & $253,268 \mathrm{sh}, 350$ & Luteolin-7-O-glycoside & Lippia umbelata \\
\hline 19 & $37.05 \pm 0.23$ & $254,267 \mathrm{sh}, 348$ & Luteolin-7-O-glycoside & $\begin{array}{c}\text { Aloysia gratissima } \\
\text { Bouchea prismatica } \\
\text { Lippia umbelata }\end{array}$ \\
\hline 20 & $37.72 \pm 0.00$ & $232 \mathrm{sh}, 254 \mathrm{sh}, 283,344$ & $\begin{array}{l}\text { 6-Hydroxyluteolin-7-O- } \\
\text { glycoside }\end{array}$ & Bouchea prismatica \\
\hline 21 & $38.10 \pm 0.00$ & 248 sh, 288sh, 327 & Phenolic acid & Lippia umbelata \\
\hline 22 & $38.76 \pm 0.00$ & 267,337 & Apigenin-7-O-glycoside & $\begin{array}{c}\text { Priva mexicana } \\
\text { Verbena bippinatifida }\end{array}$ \\
\hline 23 & $39.23 \pm 0.00$ & $297 \mathrm{sh}, 314$ & Phenolic acid & Bouchea prismatica \\
\hline 24 & $39.42 \pm 0.00$ & 267,336 & Apigenin-7-O-glycoside & Verbena bipinnatifida \\
\hline 25 & $39.29 \pm 0.26$ & 269,331 & Scutellarein derivative & $\begin{array}{l}\text { Verbena carolina } \\
\text { Verbena gracilis }\end{array}$ \\
\hline 26 & $39.51 \pm 0.08$ & 270,335 & Apigenin-7-O-glycoside & $\begin{array}{l}\text { Verbena menthifolia } \\
\text { Verbena bipinnatifida }\end{array}$ \\
\hline 27 & $39.99 \pm 0.15$ & $251 \mathrm{sh}, 287 \mathrm{sh}, 330$ & Phenolic acid & $\begin{array}{c}\text { Priva mexicana } \\
\text { Bouchea prismatica }\end{array}$ \\
\hline 28 & $40.63 \pm 0.20$ & 267,335 & Apigenin-7-O-glycoside & $\begin{array}{c}\text { Verbena bipinnatifida } \\
\text { Bouchea prismatica }\end{array}$ \\
\hline 29 & $40.04 \pm 0.16$ & 271,331 & Scutellarein derivative & $\begin{array}{c}\text { Verbena carolina } \\
\text { Verbena menthifolia } \\
\text { Verbena gracilis }\end{array}$ \\
\hline 30 & $40.41 \pm 0.00$ & $252 \mathrm{sh}, 275,343$ & 6-hydroxyluteolin derivative & Verbena menthifolia \\
\hline
\end{tabular}

\footnotetext{
${ }^{a}$ Values represent the mean and standard deviation of at least three independent analysis.
} 
Table 3. Continued...

\begin{tabular}{|c|c|c|c|c|}
\hline $\begin{array}{l}\text { Number of } \\
\text { compound }\end{array}$ & $\begin{array}{c}\text { RT }^{\mathrm{a}} \\
(\mathrm{min}) \\
\end{array}$ & $\begin{array}{c}\lambda_{\text {max }} \\
(\mathrm{nm})\end{array}$ & $\begin{array}{c}\text { Proposed types of phenolic } \\
\text { compounds }\end{array}$ & Species \\
\hline 31 & $40.79 \pm 0.00$ & $252 \mathrm{sh}, 275,342$ & 6-hydroxyluteolin derivative & Verbena menthifolia \\
\hline 32 & $40.93 \pm 0.00$ & $236 \mathrm{sh}, 253 \mathrm{sh}, 266,343$ & Chrysoeriol glycoside & Verbena bipinnatifida \\
\hline 33 & $41.42 \pm 0.00$ & $236 \mathrm{sh}, 253 \mathrm{sh}, 265,343$ & Chrysoeriol glycoside & Verbena bipinnatifida \\
\hline 34 & $41.49 \pm 0.00$ & $253,270,345$ & Eupafolin & Phyla nodiflora \\
\hline 35 & $41.22 \pm 0.00$ & 250sh, 289sh, 330 & Phenolic acid & Priva mexicana \\
\hline 36 & $41.48 \pm 0.00$ & 254,266 sh, 347 & Luteolin-7-O-glycoside & Bouchea prismatica \\
\hline 37 & $42.00 \pm 0.00$ & 289sh, 329 & Phenolic acid & Verbena menthifolia \\
\hline 38 & $42.11 \pm 0.00$ & 236sh, 251sh, 266, 343 & Chrysoeriol glycoside & Verbena bipinnatifida \\
\hline 39 & $47.82 \pm 0.25$ & 274,330 & Scutellarein derivative & $\begin{array}{c}\text { Verbena carolina } \\
\text { Verbena menthifolia } \\
\text { Verbena gracilis }\end{array}$ \\
\hline 40 & $45.20 \pm 0.00$ & 253,270 sh, 344 & Diosmetin glycoside & Phyla nodiflora \\
\hline 41 & $45.20 \pm 0.00$ & 272,328 & Scutellarein derivative & Lantana camara \\
\hline 42 & $45.57 \pm 0.00$ & 236sh, 251, 266, 342 & Chrysoeriol glycoside & Verbena bipinnatifida \\
\hline 43 & $45.74 \pm 0.00$ & $254,273,344$ & Diosmetin glycoside & Phyla nodiflora \\
\hline 44 & $46.88 \pm 0.26$ & 269,331 & Apigenin-7-O-glycoside & $\begin{array}{l}\text { Verbena menthifolia } \\
\text { Lippia umbelata }\end{array}$ \\
\hline 45 & $48.09 \pm 0.00$ & $252 \mathrm{sh}, 267,345$ & Chrysoeriol glycoside & Lippia umbelata \\
\hline 46 & $48.56 \pm 0.00$ & 266,331 & Apigenin-7-O-glycoside & Verbena bipinnatifida \\
\hline 47 & $48.63 \pm 0.00$ & 268,329 & Scutellarein derivative & Lantana camara \\
\hline
\end{tabular}

${ }^{a}$ Values represent the mean and standard deviation of at least three independent analysis.
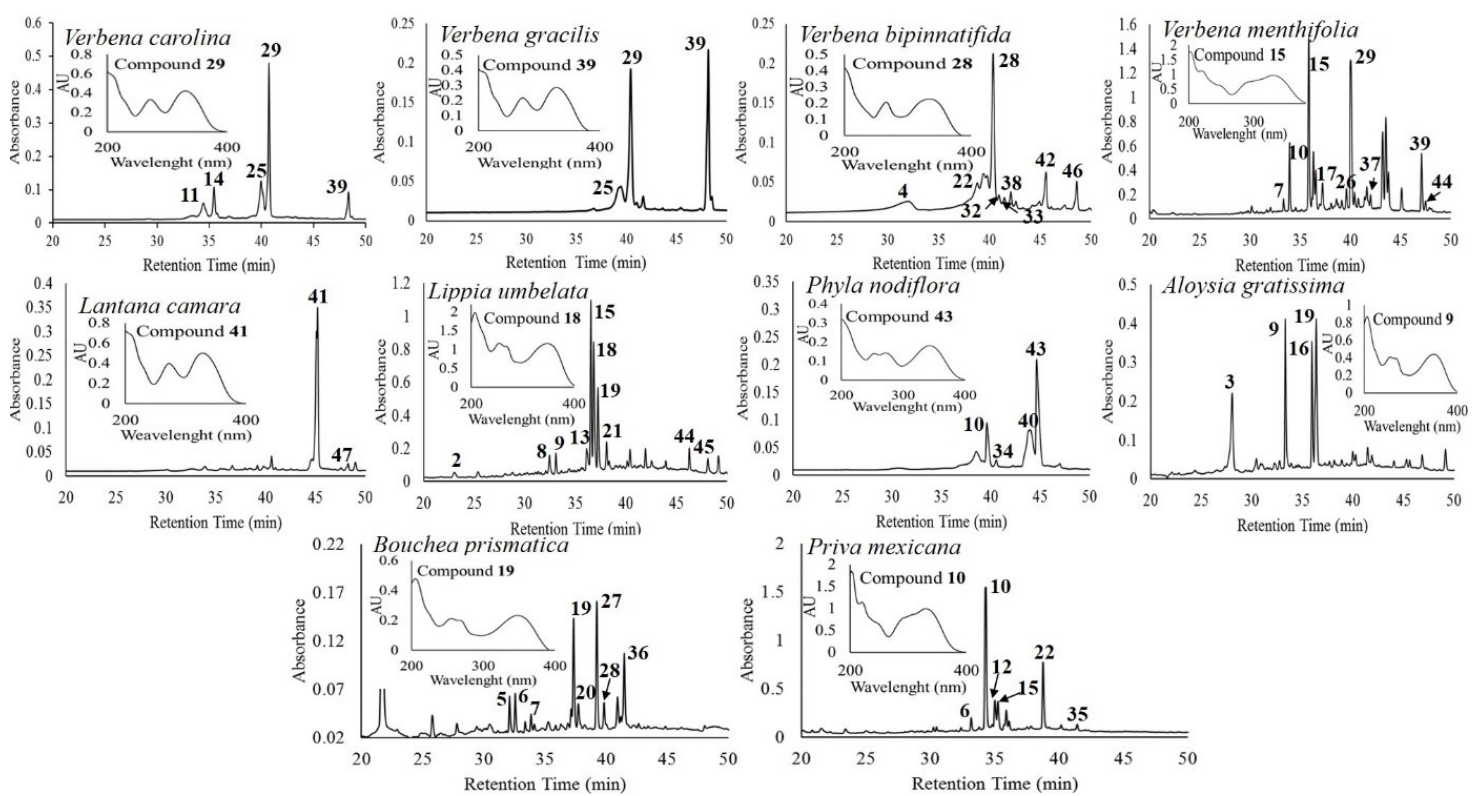

Figure 1. HPLC chromatograms (registered at $260 \mathrm{~nm}$ ) and absorption UV spectra (obtained from 200 to $400 \mathrm{~nm}$ ) of some of the major foliar phenolic compounds of 10 species of Verbenaceae. The number of compounds corresponds to those of Table 3.

(53.4 $\mathrm{mg} \mathrm{g}^{-1} \mathrm{dt}$ ) to other species of Verbenacea with antioxidant properties, such as Aloysia triphylla (L'Hér.) Britton (52 $\mathrm{mg} \mathrm{g}^{-1} \mathrm{dw}$ ) (Ranilla et al., 2010).

The foliar flavonoid contents varied significantly among all the analyzed species (Table 2), which showed higher levels (6.6 to $17.8 \mathrm{mg} \mathrm{g}^{-1} \mathrm{dt}$ ) than those reported for other species of Verbenacea, like Lampaya medicinalis (60.04 $\mu \mathrm{g} \mathrm{g}^{-1} \mathrm{dt}$ ) (Morales and Paredes, 2014).

The analyzed species had antioxidant properties. A particular and significantly different antiradical activity was found for each species analyzed, except for A. gratissima and $V$. bipinnatifida, which expressed 


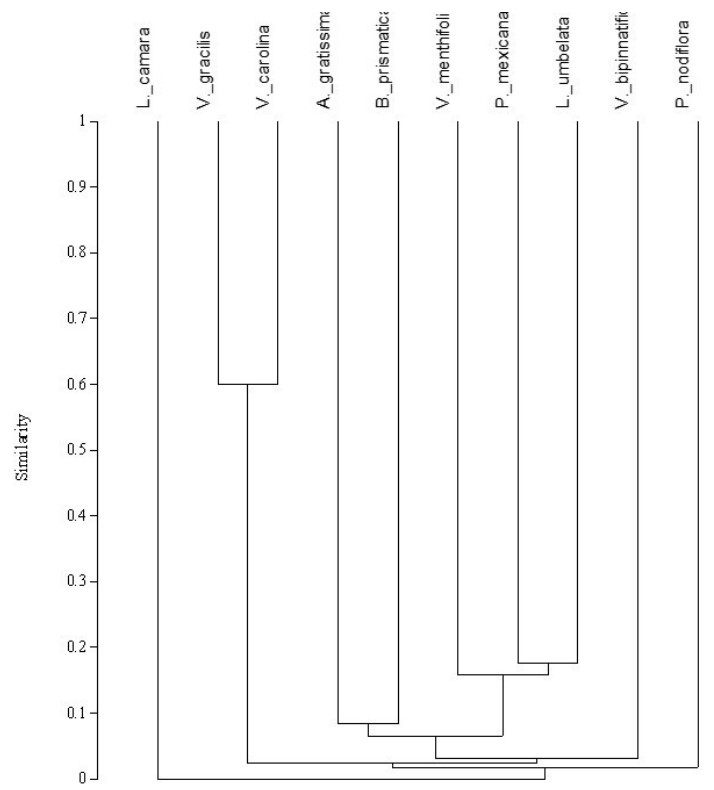

Figure 2. Results of the cluster analysis based on the comparisons of the foliar phenolic profiles of 10 species of Verbenaceae. The dendrogram was generated with the Paired Group Algorithm and the Jaccard Similarity Measure.

similar activities (Table 2). The antiradical activity of any of the analyzed species was higher than those of the standards quercetin $\left(\mathrm{EC}_{50}=5.29 \mu \mathrm{g} \mathrm{mL}^{-1}\right)$ and epicatechin $\left(\mathrm{EC}_{50}=14.33 \mu \mathrm{g} \mathrm{mL}^{-1}\right)$, both reported as phenolic compounds with important antiradical activity (Jiménez-Aliaga et al., 2011; Meng et al., 2015).

Significant differences in the iron reducing power were found, except between L. umbelata and P. mexicana (Table 2), which expressed similar iron reducing potentials. The activity of $A$. gratissima $\left(9.21 \mu \mathrm{g} \mathrm{mL}^{-1}\right)$ was comparable to that of the standard quercetin $\left(9.27 \mu \mathrm{g} \mathrm{mL}^{-1}\right)$ and the activity of seven of the analyzed species was higher than that of the standard epicatechin $\left(7.17 \mu \mathrm{g} \mathrm{mL}^{-1}\right)$. Comparatively, all analyzed species displayed higher reducing power than the edible fruits of Physalis alkekengi $\left(\mathrm{IC}_{50}=36.58 \mathrm{mg} \mathrm{mL}^{-1}\right)$ (Diaz et al., 2012).

The reducing potential of the foliar extracts of the analyzed species was also revealed by their capability to produce Mo (V) from Mo (VI) (TAC assay). The Tukey test separated the mean of each L. umbelata, V. menthifolia and $P$. mexicana in an individual group, suggesting that each of this species had a distinguishing TAC value (Table 2). All samples displayed similar or higher TAC values than the standard epicatechin $\left(2.14 \mathrm{mg} \mathrm{mL}^{-1}\right)$; however, none reached the activity of the standard quercetin $\left(8.23 \mathrm{mg} \mathrm{mL}^{-1}\right)$. Comparatively, the TAC value of $V$. menthifolia was 1.6-fold higher than that of the leaves of the Chihuahuan ground cherry (Physalis subulata Rydb.), which is $3.59 \mathrm{mg} \mathrm{mL}^{-1}$ (Medina-Medrano et al., 2015).

High correlations between the kinetic behavior of antioxidant assays and the phenolic and flavonoid contents, and unclear associations between the antioxidant activities and the phenolic and flavonoid contents in different samples have also been found by other authors (Morais et al., 2011). The current results support the proposal made by Morais et al. (2011) on the significant role of the qualitative phenolic composition, aside from the phenolic and flavonoid contents, in determining the antioxidant potentials of plant extracts.

Concerning the HPLC-DAD phenolic profiles, the results found for the analyzed species extends the groups of plants for which phenolic profiles have a species-specific condition, corroborating the proposal made by some authors on the relevance of phenolic profiles as important specific chemomarkers (Veit et al., 1995). These same authors and others (Almaraz-Abarca et al., 2013) have pointed out that under variable environmental conditions, the major changes occur in the concentrations of the individual phenolic compounds, keeping stable the qualitative composition. Thus, given the relevance of the species of Verbenaceae have in traditional medicine worldwide, the foliar phenolic patterns obtained by HPLC-DAD, which were species-specific (Figure 2), represent a chemical fingerprinting that can become an important tool of quality control regarding the specific authentication of plant-based preparations from species of Verbenaceae. The current results also suggest that the species-specific profiles found could contribute to solve taxonomic controversies concerning the establishment of specific limits in some genera of Verbenaceae, as those informed for Lantana (Ghisalberti, 2000).

Flavone glycosides and phenolic acids were the only phenolic compounds found in the leaves of Verbenaceae analyzed. These two kinds of phenolic compounds have been reported as relevant antioxidants (Catarino et al., 2015; Shin et al., 2015). Our results indicated that A. gratissima profile was constituted by one phenolic acid (3), one 7-O-glycoside of apigenin (16), and two luteolin-7-O-glycosides (9 and 19) (Table 3 and Figure 1). The current results contrast with those reported by Zeni et al. (2013) for this same species occurring in Brazil, these authors found 10 phenolic acids and no flavone in the aerial parts. These contrasting results could be accounted for by the differences between the extraction conditions. Probably, some flavonoids were degraded during the boiling water-extraction procedure used by Zeni et al. (2013), as flavonoid degradation, producing phenolic acids, has been reported under boiling water conditions (Buchner et al., 2006). The chemical differences could also be the consequence of a high genetic variability between populations of the same species growing in different and contrasting environmental conditions (like those in Brazil and in northern Mexico), between which, genic flux is unlikely to occur. Furthermore, A. gratissima represents a complex formed by 22 specific and infraspecific taxa, whose boundaries are not well-established (Moroni et al., 2016), and needs a taxonomic revision. It is possibly that the analyzed taxa from Brazil and Mexico, both identified as A. gratissima, actually represent different taxa. Aloysia 
gratissima was collected from the same location as $B$. prismatica and $V$. menthifolia (Table 1), where they are sympatric; therefore, they are exposed to the same environmental conditions. This suggests that the clearly different phenolic profiles (Figure 1) are the result of genetic specific differences, which command a species-specific sequential order in the phenolic biosynthesis, as Heller and Forkmann (1994) pointed out.

In the present study, only two glycoside derivatives of scutelarein (41 and 47) were found for L. camara (Table 3). Our results contrast with those of Wollenweber et al. (1997), who reported three quercetin derivatives (flavonols) for the leaves of this same species growing in the eastern United States. The contrasting results in the L. camara phenolic composition may have arisen from different extraction conditions (acetone extracts were prepared by Wollenweber et al., 1997), but may be also a chemical evidence of the high genetic and morphological variability of the species, which represents a complex rather than a single species (Ghisalberti, 2000) that deserves a taxonomic evaluation.

The closest chemical relationship (Figure 2) was found between $V$. carolina and $V$. gracilis, which accumulated only scutellarein derivatives and shared the compounds $\mathbf{2 5}$, 29, and 39 (Table 3 and Figure 1). The profile found for $V$. bipinnatifida was formed by one methoxy derivative of tricetin (4), four chrysoeriol glycosides (32, 33, 38 and 42), and five apigenin-3- $O$-glycosides (22, 24, 26, 28 and 46); whereas that found for $V$. menthifolia was formed by two apigenin-7-O-glycosides (26 and 44), two scutellarein derivatives (29 and 39), five luteolin derivatives (7, 13, 17, 30 and 31), and three phenolic acids (10, 15 and 37). These two profiles were among the most complex recorded here (Table 3 and Figure 1), and agreed with the flavone diversity reported by Kawashty and El-Garf (2000) for other species of Verbena.

With 10 compounds, the Lippia umbelata phenolic pattern was also complex, formed by one chrysoeriol glycoside (45), one apigenin glycoside (44), five luteolin-7- $O$-glycosides $(\mathbf{8}, \mathbf{9}, \mathbf{1 3}, 18$ and 19), and three phenolic acids (2, 15 and 21) (Table 3 and Figure 1). Complex patterns (of 15 flavones) have been reported also for other species of Lippia, like L. nodiflora (L.) Michx. and L. canescens Kunth (Tomás-Barberan et al., 1987).

The foliar phenolic profile of Phyla nodiflora was formed by two glycoside derivatives of diosmetin (40 and $\mathbf{4 3}$ ) and eupafolin (34), aside from one phenolic acid (10). Ko et al. (2014) also reported eupafolin in the aerial parts of this same species.

Bouchea and Priva are less studied genera regarding their phenolic composition. The phenolic pattern found for B. prismatica was complex, formed by two apigenin-7- $O$-glycosides (6 and 28), two phenolic acids (23 and 27), and five luteolin glycosides (5, 7, 19, 20 and 36) (Table 3 and Figure 1). A complex pattern was also found for $P$. mexicana, formed by one glycoside derivative of scutellarein (12), one luteolin-7-O-glycoside (13), two apigenin-7- $O$-glycosides (6 and 22), and six phenolic acids $(\mathbf{1}, \mathbf{2}, \mathbf{1 0}, \mathbf{1 5}, 27$ and 35). The complex profile found for $P$. mexicana contrasts with that reported for the aerial parts of other species of Priva, like P. lappulacea, for which Braga et al. (2009) only mentioned luteolin.

\section{Conclusion}

The analyzed species of Verbenaceae are important sources of antioxidant phenolic compounds. Their leaves accumulate an important diversity of flavones but some phenolic acids can also be found. The species-specific phenolic profiles found for the taxa analyzed represent fingerprintings with taxonomical implications for defining specific limits in the family and can be used as a quality control tool for determining the authenticity of herbal preparations from species of Verbenaceae.

\section{Acknowledgements}

The authors thank the Consejo Nacional de Ciencia y Tecnología for the grant (1010/508/2013. MOD. ORD./33/2013) to one of the authors and to the Comisión de Operación y Fomento a las Actividades Académicas, Instituto Politécnico Nacional for the stimuli to research.

\section{References}

AHMAD, M., KHAN, M.A., RASHID, U., ZAFAR, M., ARSHAD, M. and SULTANA, S., 2009. Quality assurance of herbal drug valerian by chemotaxonomic markers. African Journal of Biotechnology, vol. 8, no. 6, pp. 1148-1154.

ALMARAZ-ABARCA, N., GONZÁLEZ-ELIZONDO, M., TENAFLORES, J.A., ÁVILA-REYES, J.A., HERRERA-CORRAL, J. and NARANJO-JIMÉNEZ, N., 2006. Foliar flavonoids distinguish Pinus leiophylla and P. chihuahuana (Coniferales: Pinaceae). Proceedings of the Biological Society of Washington, vol. 119, no. 3, pp. 426-436. http://dx.doi.org/10.2988/0006-324X(2006) 119[426:FFDPLA]2.0.CO;2.

ALMARAZ-ABARCA, N., GONZÁLEZ-ELIZONDO, M.S., CAMPOS, M.G., ÁVILA-SEVILLA, Z.E., DELGADOALVARADO, E.A. and ÁVILA-REYES, J.A., 2013. Variability of the foliar phenolic profiles of the Agave victoriae-reginae complex (Agavaceae). Botanical Sciences, vol. 91, no. 3, pp. 295-306. http://dx.doi.org/10.17129/botsci.9.

BRAGA, J.M.F., PIMENTEL, R.M.M., FERREIRA, C.P., RANDAU, K.P. and XAVIER, H.S., 2009. Morfoanatomía, histoquímica e perfil fitoquímico de Priva lappulaceae (L.) Pers. (Verbenaceae). Revista Brasileira de Farmacognosia, vol. 19, no. 2B, pp. 516523. http://dx.doi.org/10.1590/S0102-695X2009000400002.

BUCHNER, N., KRUMBEIN, A., ROHN, S. and KROH, L.W., 2006. Effect of thermal processing on the flavonols rutin and quercetin. Rapid Communications in Mass Spectrometry, vol. 20, no. 21, pp. 3229-3235. http://dx.doi.org/10.1002/rcm.2720. PMid:17016866.

CALVO, M.I., SAN JULIAN, A. and FERNÁNDEZ, M., 1997. Identification of the major compounds in extracts of Verbena oficinalis L. (Verbenaceae) by HPLC with post-column derivatization. Chromatographia, vol. 46, no. 5-6, pp. 241-244. http://dx.doi. org/10.1007/BF02496313. 
CALZADA-SÁNCHEZ, E.V., AGUILAR-RODRÍGUEZ, S., LÓPEZ-VILLAFRANCO, M.E. and AGUILAR-CONTRERAS, A., 2014. Anatomía de hoja y tallo de Verbenaceae medicinales empleadas en México. Botanical Sciences, vol. 92, no. 4, pp. 469-480. http://dx.doi.org/10.17129/botsci.170.

CAMPOS, M.G. and MARKHAM, K.R., 2007. Structure information from HPLC and on-line measured absortion spectra-flavone, flavonols and phenolic acids. Coimbra: Coimbra University Press. 118 p.

CATARINO, M.D., ALVES-SILVA, M.J., PEREIRA, R.O. and CARDOSO, M.S., 2015. Antioxidant capacities of flavones and benefits in oxidative-stress related diseases. Current Topics in Medicinal Chemistry, vol. 15, no. 2, pp. 105-119. http://dx.doi. org/10.2174/1568026615666141209144506. PMid:25547095.

DIAZ, P., JEONG, S.C., LEE, S., KHOO, C. and KOYYALAMUDI, S.R., 2012. Antioxidant and anti-inflammatory activities of selected medicinal plants and fungi containing phenolic and flavonoid compounds. Chinese Medicine, vol. 7, no. 1, pp. 26. http://dx.doi. org/10.1186/1749-8546-7-26. PMid:23176585.

FALLEH, H., KSOURI, R., MEDINI, F., GUYOT, S., ABDELLY, C. and MAGNÉ, C., 2011. Antioxidant activity and phenolic composition of the medicinal and edible halophyte Mesembryanthemum edule L. Industrial Crops and Products, vol. 34, no. 1, pp. 1066-1071. http://dx.doi.org/10.1016/j.indcrop.2011.03.018.

GHISALBERTI, E.L., 2000. Lantana camara L. (Verbenaceae). Fitoterapia, vol. 71, no. 5, pp. 467-486. http://dx.doi.org/10.1016/ S0367-326X(00)00202-1. PMid:11449493.

GONÇALVES, J.L.S., LEITÃO, S.G., MONACHE, F.D., MIRANDA, M.M.F.S., SANTOS, M.G.M., ROMANOS, M.T.V. and WIGG, M.D., 2001. In vitro antiviral effect of flavonoid-rich extracts of Vitex poligama (Verbenaceae) against acyclovir-resistant herpex simplex virus type 1 . Phytomedicine, vol. 8 , no. 6 , pp. 477-480. http://dx.doi.org/10.1078/S0944-7113(04)70069-0. PMid:11824525.

HAMMER, Ø., HARPER, D.A.T. and RYAN, P.D., 2001 [viewed 23 May 2016]. PAST: Paleontological statistics software package for education and data analysis. Palaeontologia Electronica [online], vol. 4, no. 1, pp. 1-9. Available from: http://palaeo-electronica. org/2001_1/past/issue1_01.htm

HELLER, W. and FORKMANN, G.,1994. Biosynthesis of flavonoids. In: J. B. HARBORNE, ed. The flavonoids. Advances in research since 1986. London: Chapman \& Hall, pp. 499-535.

JIMÉNEZ-ALIAGA, K., BERMEJO-BESCÓS, P., BENEDÍ, J. and MARTÍN-ARAGÓN, S., 2011. Quercetin and rutin exhibit antiamyloidogenic and febril-disaggregating effects in vitro and potent antioxidant activity in APPswe cells. Life Sciences, vol. 89, no. 25-26, pp. 939-945. http://dx.doi.org/10.1016/j.lfs.2011.09.023. PMid:22008478.

KAWASHTY, S.A. and EL-GARF, I.A., 2000. The flavonoid chemosystematics of Egyptian Verbena species. Biochemical Systematics and Ecology, vol. 28, no. 9, pp. 919-921. http:/ dx.doi.org/10.1016/S0305-1978(99)00114-3. PMid:10913856.

KHARAZIAN, N., 2014. Chemotaxonomy and flavonoid diversity of Salmia L. (Lamiaceae) in Iran. Acta Botanica Brasílica, vol. 28 , no. 2, pp. 281-292. http://dx.doi.org/10.1590/S010233062014000200015 .

KO, H.H., CHIANG, Y.C., TSAI, M.H., LIANG, C.J., HSU, L.F., LI, S.Y., WANG, M.C., YEN, F.L. and LEE, C.W., 2014. Eupafolin, a skin whitening flavonoid isolated from Phyla nodiflora, downregulated melanogenesis: role of MAPK and Akt pathways. Journal of Ethnopharmacology, vol. 151, no. 1, pp. 386-393. http://dx.doi.org/10.1016/j.jep.2013.10.054. PMid:24212072.

MANICA-CATTANI, M.F., ZACARIA, J., PAULETTI, G., ATTI-SERAFINI, L. and ECHEVERRIGARAY, S., 2009. Genetic variation among South Brazilian accessions of Lippia alba Mill. (Verbenaceae) detected by ISSR and RAPD markers. Brazilian Journal of Biology = Revista Brasileira de Biologia, vol. 69 , no. 2, pp. 375-380. http://dx.doi.org/10.1590/S151969842009000200020. PMid:19675941.

MEDINA-MEDRANO, J.R., ALMARAZ-ABARCA, N., GONZÁLEZ-ELIZONDO, M.S., URIBE-SOTO, J.N., GONZÁLEZVALDEZ, L.S. and HERRERA-ARRIETA, Y., 2015. Phenolic constituents and antioxidant properties of five wild species of Physalis (Solanaceae). Botanical Studies, vol. 56, no. 24, pp. 1-13. http://dx.doi.org/10.1186/s40529-015-0101-y.

MENG, H.C., GAO, J., ZHENG, H.C., DAMIRIN, A. and MA, C.M., 2015. Diacetylated and acetone-conjugated flavan-3-ols as potent antioxidants with cell penetration ability. Journal of Functional Foods, vol. 12, pp. 256-261. http://dx.doi.org/10.1016/j. jff.2014.11.018.

MORAIS, M., MOREIRA, L., FEÁS, X. and ESTEVINHO, L.M., 2011. Honeybee-collected pollen from five Portuguese natural parks: palynological origin, phenolic content, antioxidant properties and antimicrobial activity. Food and Chemical Toxicology, vol. 49, no. 5, pp. 1096-1101. http://dx.doi.org/10.1016/j.fct.2011.01.020. PMid:21291944.

MORALES, G. and PAREDES, A., 2014. Antioxidant activities of Lampaya medicinalis extracts and their main chemical constituents. BMC Complementary and Alternative Medicine, vol. 14, pp. 259. http://dx.doi.org/10.1186/1472-6882-14-259. PMid:25047047.

MORONI, P., O'LEARY, N. and FILLOY, J., 2016. Species delimitation in the Aloysia gratissima complex (Verbenaceae) following the phylogenetic species concept. Botanical Journal of the Linnean Society, vol. 180, no. 2, pp. 193-212. http://dx.doi. org/10.1111/boj.12369.

PASSOS, J.L., MEIRA, R.M.S.A. and BARBOSA, L.C.A., 2009. Foliar anatomy of the species Lantana camara and L. radula (Verbenaceae). Planta Daninha, vol. 27, no. 4, pp. 689-700. http:// dx.doi.org/10.1590/S0100-83582009000400007.

PRIETO, P., PINEDA, M. and AGUILAR, M., 1999. Spectrophotometric quantitation of antioxidant capacity through the formation of a phosphomolybdenum complex: specific application to the determination of Vitamin E. Analytical Biochemistry, vol. 269, no. 2, pp. 337-341. http://dx.doi.org/10.1006/abio.1999.4019. PMid:10222007.

RANILLA, L.G., KWON, Y.I., APOSTOLIDIS, E. and SHETTY, K., 2010. Phenolic compounds, antioxidant activity and in vitro inhibitory potential against key enzymes relevant for hyperglycemia and hypertension of commonly used medicinal plants, herbs and spices in Latin America. Bioresource Technology, vol. 101, no. 12, pp. 4676-4689. http://dx.doi.org/10.1016/j.biortech.2010.01.093. PMid:20185303.

RZEDOWSKI, J. and CALDERÓN DE RZEDOWSKI, G.,2002. Flora del Bajío y regiones adyacentes. Facículo 100 Verbenaceae. Pátzcuaro: Instituto de Ecología A C. 145 p.

SATYAL, P., CROUCH, R.A., MONZOTE, L., COS, P., AWADH ALI, N.A., ALHAJ, M.A. and SETZER, W.N., 2016. The chemical diversity of Lantana camara: Analysis of essential oil samples from Cuba, Nepal, and Yemen. Chemistry \& Biodiversity, vol. 13, no. 3, pp. 336-342. http://dx.doi.org/10.1002/cbdv.201500271. PMid:26917060. 
SENA FILHO, J.G., RABBANI, A.R.C., DOS SANTOS SILVA, T.R., DA SILVA, A.V.C., SOUZA, I.A., SANTOS, M.J.B.A., JESUS, J.R., NOGUEIRA, P.C.L. and DURINGER, J.M., 2012. Chemical and molecular characterization of fifteen species from the Lantana (Verbenaceae) genus. Biochemical Systematics and Ecology, vol. 45, pp. 130-137. http://dx.doi.org/10.1016/j. bse.2012.07.024.

SHIN, H.S., SATSU, H., BAE, M.J., ZHAO, Z., OGIWARA, H., TOTSUKA, M. and SHIMIZU, M., 2015. Anti-inflammatory effect of chlorogenic acid on the IL-8 production in Caco-2 cells and the dextran sulphate sodium-induced colitis symptoms in C57BL/6 mice. Food Chemistry, vol. 168, pp. 167-175. http:// dx.doi.org/10.1016/j.foodchem.2014.06.100 PMid:25172696.

TOMÁS-BARBERÁN, F., HARBORNE, J.B. and SELF, R., 1987. Twelve 6-oxygenated flavone sulphates from Lippia nodiflora and L. canescens. Phytochemistry, vol. 26, no. 8, pp. 2281-2284. http://dx.doi.org/10.1016/S0031-9422(00)84701-9.

VEIT, M., BECKERT, C., HÖHNE, C., BAUER, K. and GEIGER, H., 1995. Interspecific and intraspecific variation of phenolics in the genus Equisetum subgenus Equisetum. Phytochemistry, vol. 38, no. 4, pp. 881-891. http://dx.doi.org/10.1016/00319422(94)00658-G.
WANG, C.Y., HUANG, S.C., LAI, Z.R., HO, Y.L., JOU, Y.J., KUNG, S.H., ZHANG, Y., CHANG, Y.S. and LIN, C.W., 2013. Eupafolin and ethyl acetate fraction of Kalanchoe gracilis stem extract show potent antiviral activities against enterovirus 71 and coxsackievirus A16. Evidence-Based Complementary and Alternative Medicine, vol. 2013, pp. 591354. http://dx.doi. org/10.1155/2013/591354. PMid:24078828.

WOLLENWEBER, E., DÖRR, M., MUNIAPPAN, R. and SIEMS, K., 1997. Flavonoid aglycones and triterpenoids from the leaf exudate of Lantana camara and Lantana montevidensis. Biochemical Systematics and Ecology, vol. 25, no. 3, pp. 269-270. http://dx.doi.org/10.1016/S0305-1978(96)00115-9.

YANG, J., GUO, J. and YUAN, J., 2008. In vitro antioxidant properties of rutin. Lebensmittel-Wissenschaft + Technologie, vol. 41, no. 6, pp. 1060-1066. http://dx.doi.org/10.1016/j. lwt.2007.06.010.

ZENI, A.L.B., ALBUQUERQUE, C.A.C., GONÇALVES, F., LATINI, A., TASCA, C.I., PODESTÁ, R., PAGLIOSA, C.M., DUARTE, F.S., LIMA, T.C.M. MARASCHIN, M. and MARASCHIN, M., 2013. Phytochemical profile, toxicity and antioxidant activity of Aloysia gratissima (Verbenaceae). Quimica Nova, vol. 36, no. 1, pp. 69-73. http://dx.doi.org/10.1590/S0100-40422013000100013. 